\title{
Dental caries in children with Down syndrome and associated factors
}

\author{
Cárie dentária em crianças com síndrome \\ de Down e fatores associados
}

\author{
Lina Naomi HASHIZUME ${ }^{1}$ iD https://orcid.org/0000-0001-5477-2768 \\ Mauricio José Santos MOREIRA ${ }^{1}$ iD https://orcid.org/0000-0001-6326-8555 \\ Juliana Balbinot HILGERT ${ }^{1}$ iD https://orcid.org/0000-0002-2204-1634
}

\section{ABSTRACT}

Objective: The aim of this study was to assess dental caries and associated factors in children with Down syndrome (DS). Methods: The sample consisted of children between 6 and 12 years old being 67 with DS and 46 without DS. Caries experience and gingival bleeding index were recorded. Questionnaire with socio-demographic questions was applied to children's caregivers. Crude and adjusted prevalence ratios for caries in primary and permanent teeth were calculated by means of Poisson regression with robust variance. Results: Children with DS and without DS showed similar results for caries experience. Only age was associated with caries at permanent teeth. None of the variables were associated with caries at primary teeth in both groups of children. Conclusion: It can be concluded that social factors and access to dental services analyzed in this study were not associated with dental caries in children with DS syndrome. Furthermore, caries experience for children with DS and those without the syndrome were not different based on this study.

Index terms: Down syndrome. Dental caries. Social indicators.

\section{RESUMO}

Objetivo: O objetivo deste estudo foi avaliar a experiência de cárie dentária e os fatores associados em crianças com síndrome de Down (SD). Métodos: A amostra consistiu de crianças de 6 a 12 anos de idade, sendo 67 crianças com SD e em 46 sem SD. A experiência de cárie e o índice de sangramento gengival foram registrados. Um questionário sociodemográfico foi aplicado aos cuidadores das crianças. Os valores brutos e ajustados das razões de prevalência para cárie dentária foram calculados através das médias da regressão de Poisson com variável robusta. Resultados: As crianças com SD e sem SD mostraram resultados similares para experiência de cárie. Somente a idade foi associada com cárie em dentes permanentes, nenhuma das variáveis foi associada com cárie em dentes decíduos para ambos os grupos de crianças. Conclusão: Pode ser concluído que os fatores sociais e o acesso a serviços odontológicos analisados neste estudo não foram associados com cárie dentária em crianças com SD. Além disso, a experiência de cárie não diferiu entre as crianças com SD e sem SD neste estudo.

Termos de indexação: Síndrome de Down. Cárie dentária. Indicadores sociais

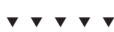

1 Universidade Federal do Rio Grande do Sul, Faculdade de Odontologia, Departamento de Odontologia Preventiva e Social. Rua Ramiro Barcelos, 2492, Santana, 90035-003, Porto Alegre, RS, Brasil. Correspondence to: LN HASHIZUME. E-mail:< Ihashizume@yahoo.com>.

$\boldsymbol{\nabla} \boldsymbol{\nabla} \boldsymbol{v}$

How to cite this article

Hashizume LN, Moreira MJS, Hilgert JB. Dental caries in children with Down syndrome and associated factors. RGO, Rev Gaúch Odontol. 2021;69:e20210044. http://dx.doi.org/10.1590/1981-863720200004420200072
} 


\section{INTRODUCTION}

Down syndrome (DS) is the most prevalent genetic alteration in the population. This genetic anomaly affects all ethnicities and socioeconomic levels occurring in approximately $1: 600$ to $1: 1,000$ live births [1]. DS is a systemic condition, characterised by musculoskeletal abnormalities, such as a flat nasal bridge, small head, nose, feet, hands, and fingers, and hypotonia; cognitive and neurological disorders, including mental retardation; and cardiac, visual, respiratory, and metabolic changes [2]. DS patients are susceptible to infections, malignant, and autoimmune diseases [3]. For unknown reasons, the most abundant infections in DS are observed in the mucosal gastrointestinal and respiratory systems [4]. Their prevalence and severity increase with age [5].

DS is also associated with some peculiarities of the oral cavity and stomatognathic system, which must be monitored to ensure adequate oral health. These aspects include frequent malocclusions, temporomandibular joint dysfunction, problems in dental alignment, and bruxism $[6,7]$. Patients with DS may also have a high, V-shaped palate, a downward angle of the mouth, lower lip eversion, mouth breathing with drooling, a chapped lower lip, and angular cheilitis. The tongue may be scalloped, fissured, and protruded, with papillary hypertrophy, and although true macroglossia is rare, there may be apparent macroglossia relative to the small oral cavity. Dental anomalies such as microdontia, hypodontia, partial anodontia, supranumerary teeth, diastema and agenesis are also common $[6,8]$.

There is no consensus in the literature regarding the potential association between DS and dental caries, because studies have produced controversial results [9]. Many report that individuals with DS have a lower prevalence of dental caries compared to non-DS individuals $[1,6,10,11]$. However, other studies did not observe differences in caries experience among individuals with and without DS $[12,13]$. Possible causes of this putative difference in prevalence of dental caries include environmental factors, such as dietary and oral hygiene habits; congenital factors; and differences in the salivary composition of individuals with DS.

Delay in tooth eruption is one of the complicating factors in trying to interpret data for Down syndrome children and caries experience. Fung and Allison investigated the caries rates in Down syndrome individuals, where the delay in tooth eruption was taken into consideration. They reported that caries experience of those participants with
Down syndrome compared to non-syndromic individuals became not significant [14].

The fact is that, dental caries still remain as an important oral health problem in Down syndrome individuals because its prevalence in this population varies $28 \%$ to $43 \%[6,15]$. Factors as socioeconomic status, caregiver's level of education and access to dental services can be associated to dental caries in the whole population and in the vulnerable groups [16].

The compromised immunity of patients with Down syndrome, added to an altered inflammatory response in the presence of plaque, makes these individuals more susceptible to the development of periodontal disease $[17,18]$.

Individuals with Down syndrome are part of a vulnerable group not only because of the difficulties imposed by their condition, but also because of the barriers imposed by the society. They are usually socially excluded, with limited access to the education and health care system to respond their needs. This can have a negative impact on their overall health status, also affecting their oral health [19].

The aim of this study was to assess the social factors associated with dental caries in primary and permanent teeth of children with Down syndrome.

\section{METHODS}

The sample comprised 113 children aged 6 to 14 years, with 67 children with DS from Medical Genetics Service of Hospital de Clínicas de Porto Alegre and 46 children without DS from a public primary school in the city of Porto Alegre, RS. This sample was a part of previous study on caries in DS children [15]. Children without DS were included in this study to compose the control group. This study was approved by the Research Ethics Committee of Hospital de Clínicas de Porto Alegre (protocol number 23211). All parents/legal guardians of study participants signed an informed consent document according to the Declaration of Helsinki [20].

The clinical examination was performed by a single well-trained examiner (MJSM) while the subjects were seated in a chair under natural light. Prior to the study, calibration sessions were held. Twenty children were examined twice with a week interval between the clinical examinations at the beginning of the study to calculate their subsequent agreement. Intra-examiner agreement for clinical examination was 0.96, which is deemed excellent according to a standard interpretation of kappa. 
The gingival bleeding index (GBI) was the first variable investigated during the clinical examination, and was recorded as presence or absence of gingival bleeding [21]. The diagnosis of caries was based on detection of carious lesions at the cavitation stage [22]. The total number of decayed, missing, and filled primary (dmft) and permanent (DMFT) teeth were recorded for each participant to characterise the epidemiological history of caries in both groups.

All caregivers of children with and without Down syndrome answered a questionnaire. The questionnaire included demographic questions concerning age and gender of the children. Data on economic status were obtained through the Brazilian Economic Classification Criteria of the Brazilian Association of Economic Research [23], which estimates the purchasing power of urban individuals and families and considers the degree of education of the head of the household. This data was classified as low, medium and high. Mother's educational level, the main responsible for the child, the mother's perception of children's oral health and access to dental services (reason and place of first visit to dentist) were also included in the questionnaire.

Chi-square tests were used to evaluate the distributions of categorical independent variables in relation to the study outcome. For age, the t-test was used to compare means in relation to the outcome, for the other variables, chi-square was calculated. Prevalence ratios (PRs) were estimated using Poisson regression with a robust variance estimator. Variables which had $p<.10$ were considered for the final, fully adjusted model. The association between the studied variables and the outcome was estimated using PRs and respective 95\% confidence intervals (Cls). Statistical significance was set at $p<.05$. All statistical analyses were performed using the SPSS version 18.0 (SPSS Inc., Chicago, IL).

\section{RESULTS}

Table 1 shows the characteristics of the study population. For the variables age, gender, family income,

Table 1. Characteristics of the studied population.

\begin{tabular}{|c|c|c|c|}
\hline Variable & Children without DS & Children with DS & $p$ value \\
\hline Age $($ mean $\pm S D)$ & $8.72 \pm 1.86$ & $8.88 \pm 2.03$ & 0.67 \\
\hline \multicolumn{4}{|l|}{ Gender } \\
\hline \multicolumn{4}{|l|}{ Main caregiver } \\
\hline Mother & $\mathrm{n}=19(41.3 \%)$ & $\mathrm{n}=51(76.1 \%)$ & $<0.01$ \\
\hline Low & $15.6 \%$ & $13.4 \%$ & 0.62 \\
\hline Medium & $66.7 \%$ & $74.7 \%$ & \\
\hline High & $17.7 \%$ & $11.9 \%$ & \\
\hline Mother's educational level & & & 0.67 \\
\hline$>11$ years & $57.2 \%$ & $59.4 \%$ & \\
\hline Reason of first visit to dentist & & & 0.82 \\
\hline Pain & $6.5 \%$ & $4.5 \%$ & \\
\hline Prevention & $65.2 \%$ & $70.1 \%$ & \\
\hline Other & $28.3 \%$ & $25.4 \%$ & \\
\hline Place of first visit to dentist & & & 0.001 \\
\hline Public dental service & $39.1 \%$ & $29.9 \%$ & \\
\hline Private dental service & $30.4 \%$ & $13.4 \%$ & \\
\hline Other & $2.2 \%$ & $31.3 \%$ & \\
\hline Never visit dentist & $28.3 \%$ & $25.4 \%$ & \\
\hline
\end{tabular}

Note: SD: standard deviation; DS: Down syndrome. 
mother's educational level, mother's perception about child's oral health, reason of first visit to dentist, and the children with and without Down syndrome presented similar results. DS children showed a higher percentage of mother as main caregiver compared to non-DS children $(p<0.05)$. Differences also were noted among the groups in relation to the place of first visit to dentist. About children who never visited dentist, it was found $25.4 \%$ in DS children and $28.3 \%$ in non-DS children.

Both groups showed similar results in dental caries experience. The DMFT and dmft (mean \pm SD) were, respectively, $0.37 \pm 1.06$ and $1.51 \pm 2.78$ for DS children and $0.5 \pm 0.91$ and $1.42 \pm 2.16$ for non-DS children. The percentage of caries free children was $56.7 \%$ in DS group and $50 \%$ in non-DS group.

Table 2 shows crude and adjusted prevalence ratio for caries in primary and permanent teeth of all studied children. Only age ( $P R=1.22$, IC95\%1.00-1.48) was associated with caries at permanent teeth $(p<0.05)$. For caries in primary teeth, none of the variables was associated.

\section{DISCUSSION}

There is a lack of evidence around the impact that disability has on oral health and what factors are related to caries experience in children of DS [9]. Therefore the present study assessed the associated factors with dental caries in children with Down syndrome.

Many studied variables were related with child's parents or caregivers as level of education, income and oral health perception. A study showed that caregivers' perception of their children's oral health status is a significant indicator of the children's clinical caries experience [24]. Caregivers with good personal oral hygiene skills are more likely to understand the importance of a child's

Table 2. Crude and adjusted prevalence ratios for caries in primary and permanent teeth of all studied children.

\begin{tabular}{|c|c|c|c|c|c|}
\hline & & \multicolumn{2}{|c|}{ Caries in primary teeth } & \multicolumn{2}{|c|}{ Caries in permanent teeth } \\
\hline & & $\operatorname{PRc}(95 \% \mathrm{Cl})$ & $\operatorname{PRa}(95 \% \mathrm{CI})$ & $\operatorname{PRc}(95 \% \mathrm{Cl})$ & $\operatorname{PRa}(95 \% \mathrm{Cl})$ \\
\hline Age & & $0.93(0.81-1.07)^{8}$ & & $1.22(1.00-1.48)^{*}$ & $1.22(1.00-1.48)^{*}$ \\
\hline Gender & Female & $0.89(0.53-1.47)^{\&}$ & & $0.64(0.89-1.47)^{\&}$ & \\
\hline Down syndrome & With DS & $0.86(0.52-1.44)^{8}$ & & $0.55(0.25-1.19)^{8}$ & \\
\hline \multirow[t]{2}{*}{ Main caregiver } & Mother & $0.77(0.44-1.36)^{\&}$ & & $0.72(0.33-1.54)^{8}$ & \\
\hline & Other & 1 & & 1 & \\
\hline \multirow[t]{2}{*}{ Mother's educational level } & $<11$ years & 1 & 1 & 1 & \\
\hline & $>11$ years & $0.60(0.35-1.01)^{\#}$ & $0.67(0.37-1.23)^{8}$ & $0.67(0.30-1.49)^{8}$ & \\
\hline \multirow{2}{*}{ Reason of first visit to dentist } & Pain & $1.78(0.69-4.61)^{8}$ & & $2.25(0.53-9.58)^{\mathbb{2}}$ & \\
\hline & Prevention & $1.00(0.55-1.83)^{\mathbb{8}}$ & & $1.33(0.48-3.66)^{8}$ & \\
\hline \multirow[t]{4}{*}{ Place of first visit to dentist } & Public dental service & $1.25(0.66-2.36)^{8}$ & & $2.19(0.79-6.05)^{\mathbb{2}}$ & \\
\hline & Private dental service & $1.02(0.80-2.15)^{\mathbb{2}}$ & & $0.88(0.22-3.53)^{\&}$ & \\
\hline & Other & $0.70(0.28-1.75)^{8}$ & & $0.61(0.12-3.04)^{8}$ & \\
\hline & Never visit dentist & 1 & & 1 & \\
\hline \multirow[t]{3}{*}{ Economic status } & High & 1 & & 1 & \\
\hline & Medium & $1.32(0.55-3.19)^{2}$ & & $1.00(0.61-6.20)^{8}$ & \\
\hline & Low & $2.04(0.78-5.31)^{2}$ & & $1.54(0.39-6.01)^{\&}$ & \\
\hline
\end{tabular}


oral health than caregivers with poor oral hygiene skills and would likely be more effective in controlling proper tooth brushing, sugary snack intake and other oral health behaviors of their children $[25,26]$. Caregivers who have better oral health habits are more likely to have children with better oral health habits. Young and disabled children depend on their caregivers to take care of their oral health needs, and caregivers play a key role in influencing the habits and health status of their children.

Parents play an important role in promoting positive attitudes and strategies toward oral health behaviours $[27,28]$. Mothers are the immediate and reliable caregivers of children in many countries, and they have a central role in providing effective guidance and positive attitudes toward oral health $[29,30]$. In the present study, mother's educational level and mother's perception about child's oral health entered in the final and fully adjusted model, however they were not statistically significant.

Recent systematic reviews of those with intellectual disabilities have found conflicting evidence regarding their oral hygiene status. Oral hygiene was found to be poorer than in adults without learning disabilities. In children with autism, oral hygiene has been found to be poorer and caries prevalence higher compared to the general population [31] and there is a question over whether children with Down syndrome have lower levels of caries as has been previously accepted [9].

One explanation for the majority of studies to show a lower caries prevalence in DS children may be the number of erupted teeth. The present study observed that DS children have significantly less permanent teeth and more deciduous teeth than in the group without DS, although both groups had the same average age (data not shown). This difference may be due to delayed eruption of permanent teeth that is characteristic in DS people. Those studies that found lower prevalence of caries in DS persons do not control this variable. Although some studies working with children at the age of mixed dentition, some of them only the DMFT or DMFS (permanent teeth) was considered $[32,33]$. Thus, it can be expected that DS children, by having fewer permanent teeth, have lower DMFT. A study that set the ratio of the number of teeth in people with and without SD also found no significant difference in caries prevalence between groups [14]. In the present study the percentage of caries free children was $56.7 \%$ in DS group and $50 \%$ in non-DS group, showing similar results. Our results agree with other studies that reported similar results for caries experience in children with and without Down syndrome [15,34].

Regarding gingival status, as assessed by the $\mathrm{GBI}$, children with DS also showed similar values compared to children without the syndrome. One possible explanation is that children with DS, who have limited manual dexterity, usually perform oral hygiene with the assistance or supervision of their parents or caregivers. Therefore, providing guidance to parents and caregivers is very important, as the oral hygiene of children with DS is highly dependent on their intervention $[15,35]$. Thus periodontal disease can be controlled in this population, even though these individuals have greater susceptibility. However the present study did not observed association between GBI index and caries experience in primary and permanent dentitions.

Other variable assessed in this study was access to dental services. Previous studies have identified a higher prevalence of caries in individuals who visited the dentist because of pain or restoration when compared with those who visited the dentist because of prevention [36,37]. A study found that those individuals who only visit the dentist when dental problem appear had worse impact of oral health on daily living and quality of life [38]. In the present study, the reason of first visit to dentist was prevention for the majority of participants with few individuals having sought dental service because of tooth pain.

Previous studies have shown that factors related to biochemical, immunological and microbiological aspects of individuals with DS can influence the development of oral diseases $[15,34,39]$. Therefore other biological and behavioral variables as intellectual impairment, motor coordination and orofacial characteristics of Down syndrome patients should also be taken into consideration when analyzing dental caries in this population. Besides that disorders in the oral cavity of people with Down syndrome may compromise their life routine, causing health problems, behavioral changes and difficulty in social interaction [40].

Despite the high prevalence of systemicmorbidities, after the onset of antibiotics and the possibility of surgical treatment for congenital heart defects, the life expectancy of patients with the syndrome has increased significantly, and the maintenance of good oral health is fundamental to guarantee the quality of life of these patients [41]. 
One of the limitations of this study was sample size. The present study used part of the sample of a previous study performed on the oral health conditions of children with Down syndrome [15]. This fact may have underestimated the relationship between the analyzed factors and the prevalence of caries in this population.

\section{CONCLUSION}

It can be concluded that the social factors and access to dental services analyzed in this study were not associated with dental caries in children with DS. Furthermore, caries experience for children with DS and those without the syndrome were not different based on this study.

\section{Collaborators}

LN HASHIZUME designed the study, analyzed the data and wrote the manuscript. MJS MOREIRA performed the experiment. JB HILGERT analyzed the data and wrote the manuscript. All authors discussed the results and commented on the manuscript at all stages.

\section{REFERENCES}

1. Fischer-Brandies H, Schmid RG, Fischer-Brandies E. Craniofacial development in patients with Down's syndrome from birth to 14 years of age. Eur J Orthod. 1986;8(1):35-42. https://doi. org/10.1093/ejo/8.1.35

2. Sherman SL, Allen EG, Bean LH, Freeman SB. Epidemiology of Down syndrome. Ment Retard Dev Disabil Res Rev. 2007;13(3):221-227. https://doi.org/10.1002/mrdd.20157

3. Ugazio AG. Down's syndrome: problems of immunodeficiency. Hum Genet Suppl. 1981; 2:33-39. https://doi.org/10.1007/9783-642-68006-9_3

4. Lockitch G, Singh VK, Puterman ML, Godolphin WJ, Sheps S, Tingle AJ, et al. Age-related changes in humoral and cellmediated immunity in Down syndrome children living at home. Pediatr Res. 1987;22(5):536-540. https://doi. org/10.1203/00006450-198711000-00013

5. Bittles $A H$, Bower $C$, Hussain R, Glasson EJ. The four ages of Down syndrome. Eur J Public Health. 2007;17(2):221-225. https://doi.org/10.1093/eurpub/ckl103

6. Areias CM, Sampaio-Maia B, Guimaraes H, Melo P, Andrade D. Caries in Portuguese children with Down syndrome. Clinics. 2011;66(7):1183-1186. https://doi.org/10.1590/S180759322011000700010

7. Shore S, Lightfoot T, Ansell P. Oral disease in children with Down syndrome: causes and prevention. Community Pract. 2010; 83(2):18-21.
8. Desai SS. Down syndrome: a review of the literature. Oral Surg Oral Med Oral Pathol Oral Radiol Endod. 1997; 84(3):279-285. https://doi.org/10.1016/\$1079-2104(97)90343-7

9. Moreira MJ, Schwertner C, Jardim JJ, Hashizume LN. Dental caries in individuals with Down syndrome: a systematic review. Int J Paediatr Dent. 2016;26(1):3-12. https://doi.org/10.1111/ ipd. 12212

10. Macho V, Palha M, Macedo AP, Ribeiro O, Andrade C. Comparative study between dental caries prevalence of Down syndrome children and their siblings. Spec Care Dentist. 2013;33(1):2-11. https://doi.org/10.1111/j.17544505.2012.00297.x

11. Cogulu D, Sabah E, Kutukculer N, Ozkinay F. Evaluation of the relationship between caries indices and salivary secretory $\lg \mathrm{A}$, salivary $\mathrm{pH}$, buffering capacity and flow rate in children with Down's syndrome. Arch Oral Biol. 2006;51(1):23-28. https:// doi.org/10.1016/j.archoralbio.2005.06.001

12. Yarat A, Akyuz S, Koc L, Erdem H, Emekli N. Salivary sialic acid, protein, salivary flow rate, $\mathrm{pH}$, buffering capacity and caries indices in subjects with Down's syndrome. J Dent. 1999;27(2):115-118. https://doi.org/10.1016/S03005712(98)00030-X

13. Oredugba FA. Oral health condition and treatment needs of a group of Nigerian individuals with Down syndrome. Downs Syndr Res Pract. 2007;12(1):72-76. https://doi:10.3104/ reports.2022

14. Fung K, Allison PJ. A comparison of caries rates in noninstitutionalized individuals with and without Down syndrome. Spec Care Dentist. 2005;25(6):302-310. https:// doi.org/10.1111/j.1754-4505.2005.tb01405.x

15. Moreira MJ, Schwertner C, Grando D, Faccini LS, Hashizume LN. Oral health status and salivary levels of mutans streptococci in children with Down syndrome. Pediatr Dent. 2015;37(4):355-360.

16. Kumar S, Tadakamadla J, Duraiswamy P, Kulkarni S. Dental caries and its socio-behavioral predictors- an exploratory cross-sectional study. J Clin Pediatr Dent. 2016; 40(3):186-192. https://doi.org/10.17796/1053-4628-40.3.186

17. Albandar JM, Susin C, Hughes FJ. Manifestations of systemic diseases and conditions that affect the periodontal attachment apparatus: case definitions and diagnostic considerations. J Clin Periodontol. 2018;45(Suppl 20):171-189. https://doi. org/10.1111/jcpe.12947

18. Scalioni FAR, Carrada CF, Martins CC, Ribeiro RA, Paiva SM. Periodontal disease in patients with Down syndrome: a systematic review. J Am Dent Assoc. 2018;149(7):628-639. https://doi.org/10.1016/j.adaj.2018.03.010

19. Haddad-Sabbagh A, Ciamponi AL, Guaré, RO. Special patients. In: Guedes-Pinto AC. Pediatric Dentistry. 7th Ed. São Paulo: Santos; 2003. p. 894-931.

20. Declaration of Helsinki [cited 2019 Oct 30]. Available from: <https://www.who.int/bulletin/archives/79(4)373.pdf>.

21. Ainamo J, Bay I. Problems and proposals for recording gingivitis and plaque. Int Dent J. 1975;25(4):229-235. 
22. World Health Organization. Oral Health Surveys: basic methods. 3 ed. Geneva: World Health Organization; 1987:53.

23. Brazilian Association of Economic Research. Brazilian Economic Classification Criteria. [cited 2017 March 3]. Available from: <http://www.abep.org/criterio-brasil>.

24. Sohn W, Taichman LS, Ismail Al, Reisine S. Caregiver's perception of child's oral health status among low-income African Americans. Pediatr Dent. 2008;30(6):480-487.

25. Poutanen R, Lahti S, Tolvanen M, Hausen $H$. Parental influence on children's oral health-related behavior. Acta Odontol Scand. 2006;64(5):286-292. https://doi. org/10.1080/00016350600714498

26. Vanagas G, Milasauskiene Z, Grabauskas V, Mickeviciene A. Associations between parental skills and their attitudes toward importance to develop good oral hygiene skills in their children. Medicina (Kaunas). 2009;45(9):718-723.

27. Poutanen R, Lahti S, Tolvanen M, Hausen $H$. Parental influence on children's oral-health- related behavior. Acta Odontol Scan. 2006;64:286-292. https://doi. org/10.1080/00016350600714498

28. Pierper K, Dressler S, Heinzel-Gutenbrunner M, Neuhauser A, Krecker M, Wunderlich K, Jablonski-Momeni A. The influence of social status on pre-school children's eating habits, caries experience and caries prevention behavior. Int J Public Health. 2012;57:207-215. https://doi.org/10.1007/s00038-011-0291-3

29. Al-Zahrani AM, Al-Mushayt AS, Otaibi MF, Wyne AH. Knowledge and attitude of Saudi mothers towards their preschool children's oral health. Pak J Med Sci. 2014;30:720-724. https://doi.org/ 10.12669/pjms.304.5069

30. Chen CC, Chiou SJ, Ting CC, Lin YC, Hsu CC, Chen FL, Lee $\mathrm{CH}$, Chen T, Chang CS, Lin YY, Huamg HL. Immigrant- native differences in caries-related knowledge, attitude, and oral health behaviors: a cross-sect ional study in Taiwan. BMC Oral Health. 2014;14:3. https://doi.org/10.1186/1472-6831-14-3

31. da Silva SN, Gimenez T, Souza RC, Mello-Moura ACV, Raggio DP, Morimoto $S$, et al. Oral health status of children and young adults with autism spectrum disorders: systematic review and meta-analysis. Int J Paediatr Dent. 2017;27(5):388-398. https://doi.org/10.1111/ipd.12274

32. Stabholz A, Mann J, Sela M, Schurr D, Steinberg D, Shapira J. Caries experience, periodontal treatment needs, salivary $\mathrm{pH}$, and Streptococcus mutans counts in a preadolescent Down syndrome population. Spec Care Dentist. 1991; 11:203-8. https://doi.org/10.1111/j.1754-4505.1991.tb01732.x
33. Barnett ML, Press KP, Friedman D, Sonnenberg EM. The prevalence of periodontitis and dental caries in a Down's syndrome population. J Periodontol. 1986; 57:288-93. https://doi.org/10.1902/jop.1986.57.5.288

34. Hashizume LN, Schwertner C, Moreira MJS, Coitinho AS, Faccini LS. Salivary secretory IgA concentration and dental caries in children with Down syndrome. Spec Care Dentist. 2017;37(3):115-119. https://doi.org/10.1111/scd.12222

35. Teitelbaum AP, Pochapski MT, Jansen JL, Sabbagh-Haddad A, Santos FA, Czlusniak GD. Evaluation of the mechanical and chemical control of dental biofilm in patients with Down syndrome. Community Dent Oral Epidemiol 2009;37:463-67. https://doi.org/10.1111/j.1600-0528.2009.00488.x

36. Nicolau B, Marcenes W, Bartley M, Sheiham A. A life course approach to assessing causes of dental caries experience: the relationship between biological, behavioral, socio-economic and psychological conditions and caries in adolescents. Caries Res. 2003;37(5):319-326. https://doi.org/10.1159/000072162

37. Cypriano S, Hugo FN, Sciamarelli MC, Tôrres LH, Sousa MDA L, Wada RS. Factors associated with the incidence of dental caries among schoolchildren living in a municipality with low prevalence of dental caries. Cien Saude Colet. 2011;16(10):4095-4106. https://doi.org/10.1590/S141381232011001100015

38. Lawrence HP, Thomson WM, Broadben JM, Poulton R. Oral health-related quality of life in a birth cohort of 32-year olds. Community Dent Oral Epidemiol. 2008;36(4):305-316. https://doi.org/10.1111/j.1600-0528.2007.00395.x

39. Schwertner C, Moreira MJ, Faccini LS, Hashizume LN. Biochemical composition of the saliva and dental biofilm of children with Down syndrome. Int J Paediatr Dent. 2016;26(2):134-140. https://doi.org/10.1111/ipd.12168

40. Kaye PL, Fiske J, Bower EJ, Newton JT, Fenlon M. Views and experiences of parents and siblings of adults with Down syndrome regarding oral heathcare: a qualitative and quantitative study. Br Dent J. 2005;198(9):571-578. https:// doi.org/10.1038/sj.bdj.4812305

41. Amaral Loureiro AC, Oliveira Costa F, Eustaquio da Costa J. The impact of periodontal disease on the quality of life of individuals with Down syndrome. Down's Syndrome Res Pract. 2007;12(1):50-54. https://doi.org/10.3104/reports.1998

Received on: $26 / 5 / 2020$ Final version resubmitted on: 3/8/2020 Approved on: 25/8/2020 